\title{
SOLAR RADIATION ESTIMATED FROM EMPIRICAL MODELS FOR THE NORTH OF MINAS GERAIS, BRAZIL
}

\author{
RADIAÇÃO SOLAR ESTIMADA POR MODELOS EMPÍRICOS PARA O NORTE DE \\ MINAS GERAIS, BRASIL
}

\author{
Valdiney José da SILVA ${ }^{1}$; Fábio Janoni CARVALHO ${ }^{1}$; Claúdio Ricardo da SILVA ${ }^{1}$; \\ Roberto Terumi ATARASSI ${ }^{1}$; Javier ALMOROX ${ }^{2}$ \\ 1. Instituto de Ciências Agrárias, Universidade Federal de Uberlândia - UFU, Uberlândia, MG, Brazil. fabiojanoni@ufu.br; \\ 2. Escuela Técnica Superior de Ingenieros Agrónomos, Madrid, Espanha.
}

\begin{abstract}
Estimating daily solar radiation $\left(R_{s}\right)$ provides an important alternative in situations where it cannot be measured by conventional pyranometers. This study used meteorological data from nine cities in the north of the Minas Gerais state, Brazil, for the period from 2008 to 2010 with the aim of evaluate the accuracy and applicability of some simple models to help regions where $R_{s}$ is impossible to be measured. Five models were evaluated for their estimates of $R_{s}$ based on simple available data. For each city studied, the equations were previously calibrated. Meteorologically based empirical models to estimate daily global solar radiation are an appropriate tool if the parameters can be calibrated for different locations. These models have the advantage of using meteorological data, which are commonly available. Based on the overall results, we conclude that the accuracy of estimation by available meteorological data is acceptable and comparable with the accuracy of classical models. Considering the greater availability of air temperature data and application in studies that do not require great accuracy in estimating $R_{s}$, all models were adequate for use. The accuracy of $R_{s}$ was only slightly improved by adding rainfall records as input variable. Therefore, in the region studied, the choice of simpler models, having as input the daily maximum and minimum air temperature would not imply large error in the estimates. For most sites, Bristow and Campbell model had the best estimate of $R_{s}$ with a $R M S E$ of $2.69 \mathrm{MJ}^{-2}$ and $R^{2}=$ 0.69 , with the possibility to calibrate with available temperature data, becoming a practical and reliable model. Hargraves model should be avoided due to its lower performance compared to the other models applied.
\end{abstract}

KEYWORDS: Meteorological models. Air temperature. Model comparison. Center of Brazil.

\section{INTRODUCTION}

Local daily solar radiation data $\left(R_{s}\right)$ is extremely important for studies involving the surface energy-balance, thermal load on buildings analysis, solar energy collecting systems, crop growth models and studies of the water requirement of irrigated crops (THORNTON; RUNNING, 1999; ROBBA, 2009).

However, $R_{s}$ data are not available in some places, due to the absence of instruments for their measurement. Thereby, empirical equations were developed to estimate $R_{s}$ from variables normally available at a majority of weather stations such as sunshine duration (Ångström, 1924), air temperature range (HARGREAVES, 1981; BRISTOW; CAMPBELL, 1984; CHEN et al., 2004), air temperature range and rainfall (DE JONG; STEWART, 1993; HUNT et al., 1998; LIU; SCOTT, 2001), air temperature and water vapor pressure (ALMOROX et al., 2011) or based on day of year (BULUT, 2003; LI et al., 2010). Those models vary with numbers of variables and complexity. It is generally recognized that sunshine duration based models yield best results (WU et al., 2007; BAKIRCI, 2009). However, sunshine duration is not commonly observed at all standard meteorological stations compared to air temperature and precipitation.

Although empirically derived and conceptually simple, the air temperature-based model is founded on theoretical concepts for energy exchange in the surface boundary layer (GOODIN et al., 1999). This model assumes radiation loading as the predominant forcing mechanism for diurnal air temperature variation. Bristow and Campbell (1984) found that the model provided accurate estimates and could account for $70-90 \%$ of $R_{s}$ at three sites in the U.S.A.

In Brazil, despite the large increase in automatic weather stations network, $R_{s}$ data are not commonly available at agricultural areas, where it is essential for the reference evapotranspiration used in irrigation management. Therefore, it is important to check simple $R_{s}$ estimation models, especially in northern of Minas Gerais, which has 46.075ha in four irrigated perimeters (Gorutuba, Lagoa Grande, Pirapora and Jaíba) (CODEVASF, 2012). The aim of this study was to evaluate the accuracy and applicability of some simple models for estimating daily values of solar radiation to the north region of Minas Gerais State, Brazil, to determinate which 
models are more reliable to be used in sites where $R_{s}$ cannot be measured.

\section{MATERIAL AND METHODS}

\section{Meteorological data}

The hourly meteorological data were obtained from nine automatic weather stations located in the cities listed in Table 1 and are shown in Figure 1. These cities are in the north of the Minas Gerais state. The stations are part of National Meteorology Institute (Instituto Nacional de
Meteorologia - INMET). The INMET represents Brazil in the World Meteorological Organization. These weather stations were acquired in 2006 but the data were only available in 2008. It was used a CM6B pyranometer (Kipp \& Zonen, Netherlands, $5 \%$ of accuracy) for measurements of daily $R_{s}$. For air temperature, QMH102 probe (Vaisala, Finland, $0.1^{\circ} \mathrm{C}$ of accuracy) and for daily rainfall a QMR102 tipping-bucket rain gauge (Vaisala, Finland, $0.2 \mathrm{~mm}$ of accuracy) was used. All data were available at the INMET official web site (INMET, 2011).

Table 1. Geographic location of meteorological stations used in the study and the mean and range of daily solar radiation $\left(R_{S}\right)$, period and percentage of omission data records for each station.

\begin{tabular}{|c|c|c|c|c|c|c|c|c|}
\hline$\overline{\text { Site }}$ & City & $\begin{array}{l}\text { Latitude } \\
\text { South }\left({ }^{\circ}\right) \\
\end{array}$ & $\begin{array}{c}\text { Longitude } \\
\text { West }\left(^{\circ}\right) \\
\end{array}$ & $\begin{array}{c}\begin{array}{c}\text { Altitude } \\
(\mathbf{m})\end{array} \\
\end{array}$ & Period & $\begin{array}{c}\text { Omission } \\
(\%)\end{array}$ & 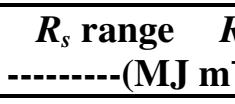 & $\begin{array}{l}R_{S} \text { mean } \\
\left.\mathrm{n}^{-2}\right)-\cdots--- \\
\end{array}$ \\
\hline 1 & $\begin{array}{c}\text { Águas } \\
\text { Vermelhas }\end{array}$ & -15.75 & -41.45 & 750 & 2009-2010 & 0.96 & $\begin{array}{l}3.19-30.70 \\
4.85-29.95\end{array}$ & $\begin{array}{l}18.10 \\
18.55\end{array}$ \\
\hline 2 & $\begin{array}{l}\text { Chapada } \\
\text { Gaúcha }\end{array}$ & -15.30 & -45.61 & 880 & 2008-2009 & 0.96 & $\begin{array}{l}4.24-31.79 \\
7.12-31.44\end{array}$ & $\begin{array}{l}20.29 \\
20.04\end{array}$ \\
\hline 3 & Espinosa & -14.91 & -42.80 & 570 & 2009-2010 & 2.05 & $\begin{array}{l}5.76-30.55 \\
7.20-30.86\end{array}$ & $\begin{array}{l}20.75 \\
21.14\end{array}$ \\
\hline 4 & Mocambinho & -15.08 & -44.01 & 460 & 2009-2010 & 0.95 & $\begin{array}{l}5.30-30.40 \\
5.88-30.49\end{array}$ & $\begin{array}{l}20.87 \\
21.04\end{array}$ \\
\hline 5 & Montalvânia & -14.40 & -44.40 & 512 & 2009-2010 & 1.10 & $\begin{array}{l}4.36-31.13 \\
7.60-31.60\end{array}$ & $\begin{array}{l}20.85 \\
21.71\end{array}$ \\
\hline 6 & Pirapora & -17.25 & -44.83 & 503 & 2008-2009 & 0.96 & $\begin{array}{l}5.44-32.67 \\
4.62-31.50\end{array}$ & $\begin{array}{l}20.42 \\
20.49\end{array}$ \\
\hline 7 & $\begin{array}{l}\text { Rio Pardo de } \\
\text { Minas }\end{array}$ & -15.72 & -42.43 & 853 & 2009-2010 & 1.92 & $\begin{array}{l}3.78-30.74 \\
3.72-30.36\end{array}$ & $\begin{array}{l}18.08 \\
18.90\end{array}$ \\
\hline 8 & Salinas & -16.16 & -42.30 & 495 & 2008-2009 & 0.55 & $\begin{array}{l}5.16-30.62 \\
3.61-30.99\end{array}$ & $\begin{array}{l}18.70 \\
18.88\end{array}$ \\
\hline 9 & São Romão & -16.36 & -45.12 & 460 & 2008-2009 & 0.96 & $\begin{array}{l}5.40-31.90 \\
4.33-31.28\end{array}$ & $\begin{array}{l}20.76 \\
20.78\end{array}$ \\
\hline
\end{tabular}

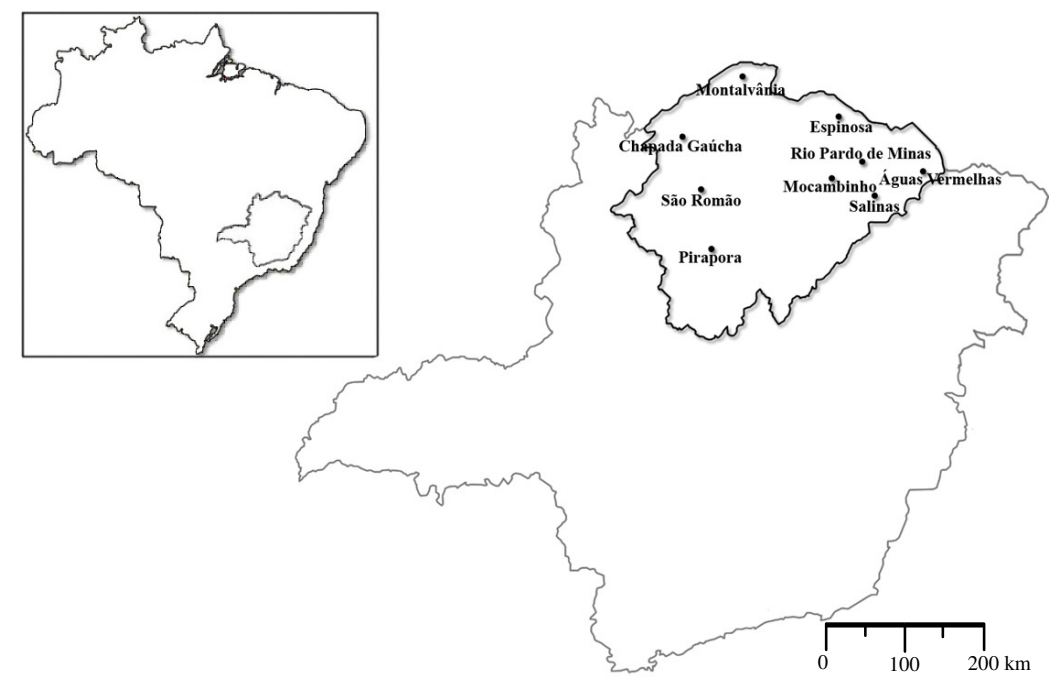

Figure 1. Distribution of stations in the north of Minas Gerais state. 
Data sets were collected from 2008 to 2010. The limited series of data was due to the automatic weather stations from National Institute of Meteorology in Brazil were acquired in 2006 but the data were available only from 2008 . For each site, a series of two years data were used in the study: the first to calibrate and the last to validate the models. Firstly, data reported at hourly intervals were reduced to daily values, obtaining the values of maximum and minimum temperatures $\left(T_{\max }, T_{\min }\right)$ and daily solar radiation $\left(R_{s}\right)$ and total rainfall $(P)$. Data were subjected to a screening to verify their integrity and consistency. Criterions for the elimination of data, proposed by Liu et al. (2009) were used. Data were discarded in the case of: a) missing data for any of the elements $T_{\max }, T_{\min }$ or $R_{s}$; b) $T_{\max }<T_{\min }$; c) $R_{S} / R_{a}>1$. The percentage of omitted days was calculated by the period considered.

\section{Radiation models}

Most models used in this study required the daily total extraterrestrial radiation $\left(R_{a}, \mathrm{MJ} \mathrm{m^{-2 }}\right)$. Therefore, $R_{a}$ was calculated using the equations detailed by Allen et al. (1998). The only input required to calculate these daily values, for a specific day of the year, is the latitude of the location.

$$
\begin{aligned}
& R_{a}=37.6 d_{r}(h n \sin \phi \sin \delta+\cos \phi \cos \delta \sin h n) \\
& d_{r}=1+0.033 \cos \left(N D A \frac{360}{365}\right) \\
& \delta=0.409 \sin \left(\frac{360}{365} N D A-1.39\right) \\
& h n=\arccos (-\tan \phi \tan \delta)
\end{aligned}
$$

where $d_{r}$ is the eccentricity correction factor of the Earth's orbit, $h n$ the hour angle of the sun at sunrise (radian), $\varnothing$ the latitude of the site (radian, south negative), $\delta$ is the solar declination (radian) and NDA is the day of year ( 1 for January first and 365 or 366 at December 31$)$.

\section{Hargreaves Model (Ha)}

Hargreaves (1981) elaborated a simple equation to estimate daily $R_{s}$ which requires only the air temperature range and $R_{a}$ :

$$
R_{s}=a \sqrt{\Delta T_{1}} R_{a}
$$

where $a$ is an empirical coefficient and $\Delta T_{l}$ is the daily maximum $\left(T_{\max }\right)$ minus minimum $\left(T_{\min }\right)$ air temperature. The coefficient $a$ must be derived for the site where data measurements are available. This model has served as the initial basis for daily solar radiation prediction by temperature-based models.
Allen et al. (1998) recommended use $a=0.16$ for interior locations, where land mass dominates and air masses are not strongly influenced by a large water body. Therefore, in order to evaluate how the Ha model with an uncalibrated coefficient $(a=0.16)$ would affect the model performance, we include it denoting as Ha-fixed.

\section{Chen et al. Model (Ch)}

Similar to the Hargreaves model, Chen et al. (2004) proposed the estimation of daily $R_{s}$ from air temperature and $R_{a}$, but using a logarithmic relationship with two coefficients:

$$
R_{s}=\left(a \ln \Delta T_{1}+b\right) R_{a}
$$

where $a$ and $b$ are empirical coefficients.

\section{Bristow and Campbell Model (B-C)}

$$
\text { Bristow and Campbell (1984) also }
$$
developed a simple equation to estimate solar radiation based on the range of air temperature $\left(\Delta T_{2}\right)$ in which $R_{s}$ is an exponential function of $\Delta T_{2}$ with three coefficients:

$$
R_{s}=a\left[1-\exp \left(-b \Delta T_{2}^{c}\right)\right] R_{a}
$$

where $a, b$ and $c$ are empirical coefficients. To help reduce the effect of large-scale hot or cold air masses which may move through the area, $\Delta T_{2}$, is calculated as the difference between maximum and average minimum air temperature of the two consecutive days as:

$$
\Delta T_{2}=T \max _{i}-\left(T \min _{i}+T \min _{i+1}\right) / 2
$$

where $i$ is the current day and $i+1$ is the next day.

These empirical coefficients have some physical explanation. The coefficient $a$ represents the maximum solar transmittance which can be expected on a clear day and the coefficients $b$ and $c$ determine how soon the maximum $R_{s}$ is achieved as $\Delta T_{2}$ increases (BRISTOW; CAMPBELL, 1984).

\section{Li et al. Model (Li)}

Since $R_{s}$ is a quasi-periodic phenomenon on a yearly cycle due to seasonal effects, sinusoidal correlations give excellent fitting (LI et al., 2010). The model uses sine and cosine wave correlations as follows:

$$
R_{s}=a+b \sin \left(\frac{2 \pi c}{365} N D A+d\right)+e \cos \left(\frac{2 \pi f}{365} N D A+g\right)
$$

where $a, b, c, d, e, f$ and $g$ are empirical coefficients and NDA is the day of year.

\section{De Jong and Stewart Model (J-S)}

Commonly, for empirical models, more input variables promote greater chance of an 
improved fit of the observed data (LIU; SCOTT, 2001). De Jong and Stewart (1993) used rainfall combined with $\Delta T_{1}$ for estimating $R_{s}$ as follows:

$$
R_{s}=a \Delta T_{1}^{b}\left(1+c P-d P^{2}\right) R_{a}
$$

where $a, b, c$ and $d$ are empirical coefficients, $P$ is the daily rainfall $(\mathrm{mm})$, and $\Delta T_{1}$ is defined as in Eq. (5).

\section{Calibration and statistical evaluation}

In the period analyzed (three years), one year was used to calibrate the coefficients of models applying the nonlinear least square fitting method. The fitting process was performed with free $R$ statistical software, version 2.13.1 through NLS function (nonlinear least-square) that outputs coefficient values and residual standard error (RSE) of the model which is the estimate of standard deviation of model error. Subsequently, the fitted models were validated using the second set of data (another year) for the same station. To ensure stability of the coefficients, solved by an iterative method using the $\mathrm{R}$ software, a range of coefficient values were used.

Models performance was evaluated in terms of the following statistical parameters: coefficient of determination $R$-squared $\left(R^{2}\right)$, root mean-square error $(R M S E)$, the mean bias error $(M B E)$ and the intercept $(a)$ and slope $(b)$ of the least-squares regression. These parameters are the most commonly applied in comparing models of solar radiation estimations (YORUKOGLU; CELIK, 2006).

\section{RESULTS AND DISCUSSION}

Li model did not fit the set of data used in this work and its results were omitted. In this model, during the fitting process, different initial values resulted in different coefficients. Li model uses only day of the year like input, which makes it more suitable to describe the normal variation of $R_{s}$ along of the year. Therefore, model calibrations that use only one year of data do not express cyclical component in the dataset. Li et al. (2010) used series of at least 10 years to calibrate the model, generating results more promising. Other models using the same approach like Bulut (2003) and Kaplanis and Kaplani (2007) would have the same restriction, requiring more than a year of data for proper calibration procedure.

Table 2. Calibrated model coefficients for all sites (1-9) for N=366 to 2008 or 365 to 2009.

\begin{tabular}{|c|c|c|c|c|c|c|c|c|c|c|c|}
\hline \multirow[t]{2}{*}{ Model } & \multicolumn{11}{|c|}{ Sites } \\
\hline & & 1 & 2 & 3 & 5 & 5 & 6 & 7 & 8 & 9 & Mean \\
\hline \multirow{2}{*}{$\mathrm{Ha}$} & $a$ & 0.150 & 0.174 & 0.179 & 0.168 & 0.159 & 0.166 & 0.157 & 0.149 & 0.160 & 0.162 \\
\hline & $R S E$ & 3.116 & 3.543 & 3.268 & 2.846 & 3.272 & 3.638 & 2.997 & 3.137 & 3.176 & \\
\hline \multirow{3}{*}{$\mathrm{Ch}$} & $a$ & 0.302 & 0.404 & 0.350 & 0.366 & 0.352 & 0.309 & 0.345 & 0.330 & 0.330 & 0.343 \\
\hline & $b$ & -0.224 & -0.389 & -0.241 & -0.327 & -0.328 & -0.186 & -0.304 & -0.301 & -0.264 & -0.285 \\
\hline & $R S E$ & 2.971 & 3.138 & 3.099 & 2.594 & 3.083 & 3.392 & 2.663 & 2.865 & 2.861 & \\
\hline \multirow{4}{*}{ B-C } & $a$ & 0.789 & 0.737 & 0.704 & 0.697 & 0.720 & 0.674 & 0.738 & 0.753 & 0.706 & 0.724 \\
\hline & $b$ & 0.046 & 0.012 & 0.012 & 0.009 & 0.015 & 0.006 & 0.039 & 0.036 & 0.009 & 0.020 \\
\hline & $c$ & 1.272 & 2.059 & 2.149 & 2.166 & 1.854 & 2.451 & 1.445 & 1.396 & 2.127 & 1.880 \\
\hline & $R S E$ & 2.84 & 2.936 & 2.817 & 2.464 & 3.1 & 2.932 & 2.761 & 2.905 & 2.541 & \\
\hline \multirow{6}{*}{$\mathrm{J}-\mathrm{S}$} & $a$ & 0.126 & 0.120 & 0.185 & 0.149 & 0.143 & 0.246 & 0.098 & 0.107 & 0.176 & 0.150 \\
\hline & $b$ & 0.573 & 0.660 & 0.495 & 0.552 & 0.544 & 0.362 & 0.689 & 0.629 & 0.472 & 0.553 \\
\hline & $c$ & -0.014 & -0.013 & -0.020 & -0.004 & -0.013 & -0.023 & -0.007 & -0.008 & -0.011 & -0.013 \\
\hline & $d$ & $1.5 \mathrm{E}-4$ & $1.3 \mathrm{E}-4$ & $3.5 \mathrm{E}-4$ & $5.6 \mathrm{E}-6$ & $2.6 \mathrm{E}-4$ & $3.8 \mathrm{E}-4$ & $8.8 \mathrm{E}-5$ & $9.9 \mathrm{E}-5$ & 8.9E-5 & - \\
\hline & $R S E$ & 2.899 & 3.062 & 2.987 & 2.707 & 3.17 & 3.252 & 2.72 & 2.919 & 2.952 & \\
\hline & $R_{\text {smean }}$ & 18.1 & 20.29 & 20.75 & 20.87 & 20.85 & 20.42 & 18.08 & 18.7 & 20.76 & \\
\hline
\end{tabular}

$* a, b, c$ and $d$ : fitted coefficients of the models; RSE: residual standard error (MJ m-2) of nonlinear model fitting; Rsmean: mean daily solar radiation (MJ m-2). $N$ : number of data used in calibration. Models- Ha: Hargreaves; Ch: Chen et al.; B-C: Bristow and Campbell; J-S: De Jong and Stewart. Sites- 1: Águas Vermelhas; 2: Chapada Gaúcha; 3: Espinosa; 4: Mocambinho; 5: Montalvânia; 6: Pirapora; 7: Rio Pardo de Minas; 8: Salinas; 9:São Romão.

The B-C model resulted in improved fit, with average $R S E$ of $2.81 \mathrm{MJ} \mathrm{m}-2$, and the $\mathrm{Ha}$ had the worst, with an average $R S E$ of $3.22 \mathrm{MJ} \mathrm{m}-2$. The $\mathrm{Ch}$ and the J-S models presented similar average $R S E$ of about 2.96 MJ m-2. Despite the differences, all $R S E$ values are similar, indicating that all models similarly describe the variation of $R_{s}$.

For the Ha model, the coefficient varied from 0.149 to 0.179 with 0.162 in average and close to 0.16 suggested by Allen et al. (1998) without calibration. The $\mathrm{Ch}$ model coefficients ranged from 
$a=0.302$ to 0.404 and $b=-0.389$ to -0.186 with averaged values of $a=0.343$ and $b=-0.285$, being close to the original calibration ( $a=0.28$ and $b=-$ $0.15)$.

For the B-C model, $a$ ranged from 0.697 to 0.789 with an average of 0.724. Typical values for $a$ is 0.7 (MEZA; VARAS, 2000). Liu et al. (2009) observed in China a trend of larger $a$ coefficient in areas with higher altitude and lower rainfall (drier climate), where the values of $a$ increased from 0.11 (lower altitudes) to 0.29 (higher altitudes). This sensitivity depends upon the local partitioning of solar energy that varies with altitude and season (LIU et al., 2009). In the present work, $b$ ranged between 0.006 and 0.046 with an average of 0.020 and $c$ ranged between 1.272 and 2.127 with an average of 1.879. In general, the coefficients remained within the range of calibrations obtained for other locations according researches of Liu and
Scott (2001), Liu et al. (2009) and Almorox et al. (2011).

For the J-S model, low values for coefficients $c$ and $d$ indicate reduced influence of rainfall as compared to air temperature on estimation of $R_{s}$. Therefore, the inclusion of rainfall improves slightly the model, which is evident by the lower value of $R S E$. In part, this is explained by the fact that the number of days without rain was greater for all locations studied, making rainfall less important.

\section{Model performance}

The models that use air temperature data only (B-C, Ch and $\mathrm{Ha}$ ) had a mean $R 2$ value close to 0.60 (Table 3). For most sites, the B-C model resulted in the highest $R 2$ (0.69) compared to the other models. There is no reference values for $R 2$, but higher values indicate a more parsimonious model.

Table 3. Performance of models by $R 2, R M S E, M B E$ errors and the intercept $(a)$ and slope $(b)$ of the linear regression between observed and estimated daily solar radiation for the North of Minas Gerais State for 2009 or 2010.

\begin{tabular}{|c|c|c|c|c|c|c|}
\hline \multirow[t]{2}{*}{ Sites } & \multirow[t]{2}{*}{ Model } & \multicolumn{2}{|c|}{ Parameters } & \multirow[t]{2}{*}{$R 2$} & \multirow{2}{*}{\multicolumn{2}{|c|}{ 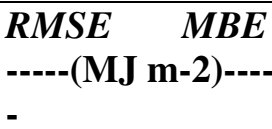 }} \\
\hline & & $A$ & $b$ & & & \\
\hline \multirow{5}{*}{$\begin{array}{l}\text { 1.Águas Vermelhas } \\
\qquad N=362 \\
R_{\text {smean }}=18.55\end{array}$} & B-C & 6.02 & 0.69 & 0.707 & 2.923 & -0.193 \\
\hline & $\mathrm{Ch}$ & 6.81 & 0.64 & 0.695 & 2.982 & 0.178 \\
\hline & $\mathrm{J}-\mathrm{S}$ & 5.55 & 0.69 & 0.705 & 2.923 & -0.108 \\
\hline & $\mathrm{Ha}$ & 8.32 & 0.56 & 0.663 & 3.200 & 0.196 \\
\hline & Ha-fixed & 8.31 & 0.56 & 0.664 & 3.195 & 0.200 \\
\hline \multirow{5}{*}{$\begin{array}{l}\text { 2.Chapada Gaúcha } \\
\qquad N=361 \\
R_{\text {smean }}=20.04\end{array}$} & B-C & 5.20 & 0.74 & 0.712 & 2.707 & -0.009 \\
\hline & $\mathrm{Ch}$ & 6.60 & 0.66 & 0.641 & 3.016 & -0.095 \\
\hline & $\mathrm{J}-\mathrm{S}$ & 6.32 & 0.67 & 0.687 & 2.835 & -0.311 \\
\hline & $\mathrm{Ha}$ & 10.49 & 0.48 & 0.540 & 3.437 & 0.040 \\
\hline & Ha-fixed & 10.47 & 0.48 & 0.541 & 3.419 & 0.024 \\
\hline \multirow{5}{*}{$\begin{array}{c}\text { 3.Espinosa } \\
N=355 \\
R_{\text {smean }}=21.14\end{array}$} & B-C & 8.19 & 0.63 & 0.604 & 2.991 & 0.418 \\
\hline & $\mathrm{Ch}$ & 9.35 & 0.57 & 0.538 & 3.228 & 0.291 \\
\hline & $\mathrm{J}-\mathrm{S}$ & 8.55 & 0.60 & 0.631 & 2.878 & 0.187 \\
\hline & $\mathrm{Ha}$ & 10.58 & 0.51 & 0.498 & 3.353 & 0.200 \\
\hline & Ha-fixed & 10.92 & 0.49 & 0.514 & 3.265 & 0.212 \\
\hline \multirow{5}{*}{$\begin{array}{l}\text { 4.Mocambinho } \\
\quad N=362 \\
R_{\text {smean }}=21.04\end{array}$} & B-C & 6.78 & 0.69 & 0.677 & 2.754 & 0.265 \\
\hline & $\mathrm{Ch}$ & 7.94 & 0.64 & 0.639 & 2.928 & 0.384 \\
\hline & $\mathrm{J}-\mathrm{S}$ & 8.73 & 0.61 & 0.631 & 2.969 & 0.418 \\
\hline & $\mathrm{Ha}$ & 10.83 & 0.50 & 0.566 & 3.231 & 0.397 \\
\hline & Ha-fixed & 10.83 & 0.50 & 0.566 & 3.232 & 0.396 \\
\hline \multirow{5}{*}{$\begin{array}{c}\text { 5.Montalvânia } \\
\quad N=362 \\
R_{\text {smean }}=21.71\end{array}$} & B-C & 7.84 & 0.64 & 0.582 & 3.069 & 0.089 \\
\hline & $\mathrm{Ch}$ & 7.96 & 0.64 & 0.591 & 3.032 & 0.343 \\
\hline & $\mathrm{J}-\mathrm{S}$ & 9.30 & 0.58 & 0.564 & 3.122 & 0.251 \\
\hline & $\mathrm{Ha}$ & 10.27 & 0.53 & 0.551 & 3.161 & 0.142 \\
\hline & Ha-fixed & 10.96 & 0.50 & 0.502 & 3.324 & 0.151 \\
\hline \multirow{2}{*}{$\begin{array}{c}\text { 6. Pirapora } \\
N=361\end{array}$} & B-C & 4.56 & 0.76 & 0.760 & 2.754 & -0.398 \\
\hline & $\mathrm{Ch}$ & 7.23 & 0.61 & 0.716 & 3.147 & -0.789 \\
\hline
\end{tabular}




\begin{tabular}{cllllll}
$R_{\text {smean }}=20.49$ & J-S & 8.30 & 0.57 & 0.679 & 3.302 & -0.620 \\
& Ha & 8.97 & 0.52 & 0.678 & 3.391 & -0.785 \\
& Ha-fixed & 8.63 & 0.51 & 0.689 & 3.631 & -1.470 \\
\hline 7.Rio Pardo de & B-C & 5.93 & 0.67 & 0.684 & 3.157 & -0.337 \\
Minas & Ch & 5.80 & 0.67 & 0.705 & 3.061 & -0.371 \\
$N=361$ & J-S & 5.94 & 0.65 & 0.698 & 3.126 & -0.526 \\
$R_{\text {smean }}=18.90$ & Ha & 8.20 & 0.55 & 0.671 & 3.325 & -0.328 \\
& Ha-fixed & 8.37 & 0.56 & 0.670 & 3.281 & 0.045 \\
\hline \multirow{2}{*}{ 8.Salinas } & B-C & 4.87 & 0.70 & 0.788 & 3.194 & -0.767 \\
$N=361$ & Ch & 4.93 & 0.70 & 0.800 & 3.134 & -0.762 \\
$R_{\text {smean }}=18.88$ & J-S & 5.81 & 0.65 & 0.799 & 3.234 & -0.755 \\
& Ha & 7.57 & 0.57 & 0.807 & 3.408 & -0.513 \\
& Ha-fixed & 8.11 & 0.61 & 0.807 & 3.317 & 0.791 \\
\hline \multirow{2}{*}{ 9.São Romão } & B-C & 2.44 & 0.80 & 0.709 & 3.382 & -1.627 \\
$N=361$ & Ch & 5.57 & 0.65 & 0.717 & 3.308 & -1.609 \\
$R_{\text {smean }}=20.78$ & J-S & 7.29 & 0.59 & 0.714 & 3.247 & -1.271 \\
& Ha & 8.67 & 0.52 & 0.702 & 3.440 & -1.340 \\
& Ha-fixed & 8.69 & 0.52 & 0.701 & 3.421 & -1.304 \\
\hline
\end{tabular}

$N$ : number of data evaluation set; $R_{\text {smean }}:$ mean daily solar radiation observed (MJ m-2). Models- B-C: Bristow and Campbell; Ch: Chen et al.; J-S: De Jong and Stewart; Ha: Hargreaves.

Models with $R 2$ higher than 0.60 showed a good quality of adjustment with researchers who used same models (YORUKOGLU, CELIK, 2006; ABRAHA, SAVAGE, 2008; ALMOROX et al., 2011). When using both rainfall and air temperature data (J-S), $R 2$ was 0.61 . This suggests that despite the inclusion of rainfall in the $\mathrm{J}-\mathrm{S}$ model, it resulted in little improvement in R2. For RMSE, a better performance for all sites was obtained using the B-C model, with a mean value of $2.69 \mathrm{MJ} \mathrm{m}-2$, followed by the models of Ch (2.76 MJ m-2), J-S (2.78 MJ $\mathrm{m}-2)$ and $\mathrm{Ha}(2.99 \mathrm{MJ} \mathrm{m}-2)$. The RMSE for each location and model followed the same sequence as for the $R S E$ values from calibration, except for the São Romão station, where improved performance was obtained using the J-S model. Similar trends in $R M S E$ and $R S E$ is an indication of similar data distribution in calibration and performance data set. Generally, the values of the RMSE decrease as the $R 2$ increase (YORUKOGLU, CELIK, 2006).

The results for $M B E$ were similar for the various models ranging from -1.627 to $0.418 \mathrm{MJ}$ m2 for B-C model, -1.609 to $0.418 \mathrm{MJ} \mathrm{m}-2$ for $\mathrm{Ch}$ model, -1.271 to $0.418 \mathrm{MJ} \mathrm{m}-2$ for J-S model and 1.340 to $0.397 \mathrm{MJ}$ m-2 d-1 for the Ha model. In general, there was an underestimation in $R_{s}$. The greater absolute $M B E$ values for air temperature based models were found for São Romão and Salinas sites, probably due to lower air temperature range in validation data set compared to the calibration set. Many factors besides $R_{s}$ could affect levels of maximum and minimum air temperature, especially on a daily basis, e.g. cloudiness, wind speed, atmospheric water vapor content, availability of soil water for evaporation, elevation, precipitation, aerosol, frontal weather systems and others (ALLEN, 1997). These factors confound the relationship used in air temperature based solar radiation models. Improvement in model performance was evident for increased elevation and days with clear sky events. Larger $\Delta T$ generally results in better predictive accuracy (Liu et al., 2009). Abraha and Savage (2008) found that the B$\mathrm{C}$ model was improved with higher elevations than with lower ones. This could be due to reduced attenuation of $R_{s}$ and therefore more heating of the air.

The intercept $(a)$ and slope $(b)$ of linear regression provide information about trends of models throughout the observed $R_{s}$. The B-C model had lower values of $a(2.44-8.19)$ and $b$ was closer to $1(0.63-0.80)$ when compared with other models at all sites. Otherwise, Ha and Ha-fixed models had the highest values of $a(7.57-10.96)$ and the lowest for $b$ (0.48-0.61). High values for parameter $a$ and lower for $b$ can lead to an overestimate of lower values of $R_{s}$ and an underestimate of higher values of $R_{s .}$. In the north of Minas Gerais, most of rainfed crops are cultivated in the beginning of the rainy season. It coincides with longer period of cloudy days and hence a greater number of days with lower values of $R_{s}$. Therefore, Ha and Ha-fixed models may be inappropriate in crop yield and evapotranspiration simulation models because in cloudy days the observed $R_{s}$ had lower values.

Results for the Ha-fixed model were very closed to the Ha model, confirming that it can be used without calibration. However, it showed poor 
performance. The Ha model is the best-known air temperature model due to its simplicity, as uses only one coefficient. However, this leads to less adjustment freedom. Borges et al. (2010), on the other hand, found that the Ha model had the best performance of three uncalibrated air temperature models $\left(R 2=0.68, R M S E\right.$ of $\left.4.76 \mathrm{MJ} \mathrm{m}^{-2}\right)$ in Cruz das Almas, Brazil, using data from the years of 2004 to 2006, also from an automatic meteorological station of INMET. However, they did not evaluate Bristow-Campbell model.

\section{CONCLUSIONS}

The accuracy of estimation via available meteorological data was acceptable and comparable with the accuracy of classical models.

The accuracy of $R_{s}$ was only slightly improved by adding rainfall records as input variable. Therefore, in the region studied, the choice of simpler models, having as input the daily maximum and minimum air temperature would not imply large error in the estimates.

For the set of data used in the current study, the model based only in the number of the year was not acceptable. In this case, datasets with a large period of time could generate more satisfactory results, given the characteristics of this model.

For most sites, Bristow and Campbell model had the best estimate of $R_{s}$ with a RMSE of $2.69 \mathrm{MJ}$ $\mathrm{m}^{-2}$ and $R^{2}=0.69$, with the possibility to calibrate with available temperature data, becoming a practical and reliable model.

Hargraves model should be avoid due to its lower performance compared to the other models applied.

RESUMO: A estimativa da radiação solar diária $\left(R_{s}\right)$ fornece uma alternativa importante em situações que não pode ser medida por piranômetros convencionais. O estudo utilizou dados meteorológicos de nove cidades do Norte do estado de Minas Gerais, Brasil, durante o período de 2008 a 2010, com o objetivo de mensurar a precisão e aplicabilidade de modelos empíricos simples nas regiões onde a $R_{s}$ não pode ser medida . Cinco modelos foram avaliados para estimar $R_{s}$ com base nos dados meteorológicos disponíveis. As equações foram previamente calibradas para cada município estudado. Modelos meteorológicos empíricos que estimam a radiação solar diária são ferramentas adequadas desde que os parâmetros sejam calibrados para os diferentes locais a serem utilizados. Estes modelos têm a vantagem de utilizar dados meteorológicos, que estão comumente disponíveis. Todos os modelos foram considerados adequados para o uso, considerando-se a maior disponibilidade de dados de temperatura do ar e aplicação em estudos que não exigem grande precisão na estimativa da $R_{s}$. A precisão da $R_{s}$ apenas foi melhorada pela adição de registros de precipitação como variável de entrada. Assim, na região estudada, a escolha de um modelo mais simples, tendo como entrada a temperatura mínima e máxima do ar diária, não implica um grande erro na estimativa. Para a maioria das regiões, o modelo de Bristow e Campbell teve a melhor estimativa da $R_{s}$ com um $R M S E$ de $2.69 \mathrm{MJ} \mathrm{m}^{-2}$ e $R^{2}=0.69$, e a possibilidade de calibração com os dados de temperatura disponíveis, tornando-se um modelo prático e confiável. O modelo de Hargraves deve ser evitado devido seu pior desempenho comparado aos outros modelos propostos.

PALAVRAS-CHAVE: Modelos meteorológicos. Temperatura do ar. Comparação de modelos. Centro do Brasil.

\section{REFERENCES}

ABRAHA, M. G.; SAVAGE, M. J. Comparison of estimates of daily solar radiation from air temperature range for application in crop simulations. Agricultural and Forest Meteorology, Connecticut, v. 148, p. 401-416, 2008. http://dx.doi.org/10.1016/j.agrformet.2007.10.001

ALLEN, R. G. Self-calibration method for estimating solar radiation from air temperature. Journal of Hydrologic Engineering, Indiana, v. 2, p. 56-67, 1997. http://dx.doi.org/10.1061/(ASCE)10840699(1997)2:2(56)

ALLEN, R. G.; PEREIRA, L. S.; RAES, D.; SMITH, M. Crop evapotranspiration: guidelines for computing crop water requirements. Roma: FAO Irrigation and Drainage Paper 56, 1998. 300p. 
ALMOROX, J.; HONTORIA, C.; BENITO, M. Models for obtaining daily global solar radiation with measured air temperature data in Madrid (Spain). Applied Energy, Connecticut, v. 88, p. 1703-1709, 2011. http://dx.doi.org/10.1016/j.apenergy.2010.11.003

ÅNGSTRÖM, A. Solar and terrestrial radiation. Quarterly Journal of the Royal Meteorological Society, Berks, v. 50, p. 121-126, 1924.

BAKIRCI, K. Correlations for estimation of daily global solar radiation with hours of bright sunshine in Turkey. Energy, Aalborg, v. 34, p. 485-501, 2009. http://dx.doi.org/10.1016/j.energy.2009.02.005

BORGES, V. P.; DE OLIVEIRA, A. S.; COELHO FILHO, M. C.; DA SILVA, T. S. M.; PAMPONET, R. M. Evaluation of models for estimating solar radiation in Cruz das Almas, Bahia. Revista Brasileira de Engenharia Agrícola e Ambiental, Campo Grande, v. 14, p. 74-80, 2010. http://dx.doi.org/10.1590/S141543662010000100010

BRISTOW, K. L.; CAMPBELL, G. S. On the relationship between incoming solar radiation and daily maximum and minimum temperature. Agricultural and Forest Meteorology, Connecticut, v. 31, p. 159-166, 1984. http://dx.doi.org/10.1016/0168-1923(84)90017-0

BULUT, H. Generation of typical solar radiation data for Istanbul. International Journal of Energy Research Applied Energy, Connecticut, v. 84, p. 477-491, 2003. http://dx.doi.org/10.1016/j.apenergy.2006.10.003

CHEN, R. S.; ERSI, K.; YANG, J. P.; LU, S. H.; ZHAO, W. Z. Validation of five global radiation models with measured daily data in China. Energy Conversion and Management, United Kingdom, v. 45, p. 1759-1769, 2004. http://dx.doi.org/10.1016/j.enconman.2003.09.019

CODEVASF. The north of Minas. Available at: <http://www.codevasf.gov.br/principal/perimetrosirrigados/polos-de-desenvolvimento-1/norte-de-minas >. Accessed Mar. 03, 2012 (in portuguese).

DE JONG, R.; STEWART, D. W. Estimating global solar radiation from common meteorological observations in western Canada. Canadian Journal of Plant Science, Canadá, v. 73, p. 509-518, 1993.

http://dx.doi.org/10.4141/cjps93-068

GOODIN, D. G.; HUTCHINSON, J. M. S.; VANDERLIP, R. L.; KNAPP, M. C. Estimating solar irradiance for crop modeling using daily air temperature data. Agronomy Journal, Madison, v. 91, p. 845-851, 1999. http://dx.doi.org/10.2134/agronj1999.915845x

HARGREAVES, G. H. Responding to tropical climates. In: Proceedings of the The Food and Climate Forum, The 1980-81 Food and Climate Review. Boulder: Aspen Institute for Humanistic Studies, p. 29-32, 1981.

HUNT, L. A.; KUCHAR, L.; SWANTON, C. J. Estimation of solar radiation for use in crop modeling. Agricultural and Forest Meteorology, Connecticut, v. 91, p. 293-300, 1998. http://dx.doi.org/10.1016/S01681923(98)00055-0

Instituto Nacional de Meteorologia. 2011. Available at: < http://www.inmet.gov.br/>. Accessed Apr. 07, 2011 (in portuguese).

KAPLANIS, S.; KAPLANI, E. A model to predict expected mean and stochastic hourly global solar radiation I(h;nj) values. Renewable Energy, Cyprus, v. 32, p. 1414-1425, 2007.

http://dx.doi.org/10.1016/j.renene.2006.06.014

LI, H.; MA, W.; LIAN, Y.; WANG, X. Estimating daily global solar radiation by day of year in China. Applied Energy, Connecticut, v. 87, p. 3011-3017, 2010. http://dx.doi.org/10.1016/j.apenergy.2010.03.028 
LIU, D. L.; SCOTT, B. J. Estimation of solar radiation in Australia from rainfall and temperature observations. Agricultural and Forest Meteorology, Connecticut, v. 106, p. 41-59, 2001. http://dx.doi.org/10.1016/S01681923(00)00173-8

LIU, X.; MEI, X.; LI, Y.; WANG, Q.; JENSEN, R.J.; ZHANG, Y.; PORTER, J. R. Evaluation of temperaturebased global solar radiation models in China. Agricultural and Forest Meteorology, Connecticut, v. 149, p. 1433-1446, 2009. http://dx.doi.org/10.1016/j.agrformet.2009.03.012

MEZA, F.; VARAS, E. Estimation of mean monthly solar global radiation as a function of temperature. Agricultural and Forest Meteorology, Connecticut, v. 100, p. 231-241, 2000.

http://dx.doi.org/10.1016/j.agrformet.2009.03.012

ROBBA, S. M. Validation of the existing models for estimating global solar radiation over Egypt. Energy Conversion and Management, United Kingdom, v. 50, p. 184-193, 2009.

http://dx.doi.org/10.1016/j.enconman.2008.07.005

THORNTON, P. E.; RUNNING, S. W. An improved algorithm for estimating incident daily solar radiation from measurements of temperature, humidity and precipitation. Agricultural and Forest Meteorology, Connecticut, v. 93, p. 211-228, 1999. http://dx.doi.org/10.1016/S0168-1923(98)00126-9

WU, G.; LIU, Y.; WANG, T. Methods and strategy for modeling daily global solar radiation with measured meteorological data - A case study in Nanchang station, China. Energy Conversion and Management, United Kingdom, v. 48, p. 2447-2452, 2007. http://dx.doi.org/10.1016/j.enconman.2007.04.011

YORUKOGLU, M.; CELIK, A. N. A critical review on the estimation of daily global solar radiation from sunshine duration. Energy Conversion and Management, United Kingdom, v. 47, p. 2441-2450, 2006. http://dx.doi.org/10.1016/j.enconman.2005.11.002 